\title{
HUBUNGAN ANTARA PENGETAHUAN PENGELOLAAN SAMPAH DENGAN PERILAKU PEDULI LINGKUNGAN (Studi Korelasional Pada Mahasiswa STKIP Melawi)
}

\author{
Ahmad Khoiri ${ }^{1}$, Eko Rudiansyah ${ }^{2}$ \\ ${ }^{1,2}$ Dosen STKIP Melawi \\ J1. RSUD Melawi km. 04 Kec.Nanga Pinoh Kab. Melawi Kalimantan Barat \\ ahmadkhoiri2290@gmail.com, ekorudiansyah90@gmail.com
}

\begin{abstract}
The purpose of this study was to obtain a picture of the relationship between students' knowledge about waste management and environmental care behavior. It is expected that students can realize the importance of behaving in a caring environment. This study used a survey method with a correlational approach, the research population of STKIP Melawi students and this student sample was 100 taken by random sampling. Data was collected using an instrument form in the form of statement items and questions. Analysis and interpretation of data shows that there is a positive relationship between student knowledge about waste management and environmental care behavior. The contribution given by the variable of student knowledge about waste management to environmental care behaviors was $46.1 \%$. The findings of this study conclude that an increase in student knowledge about waste management with environmental care behavior can increase students on the importance of protecting the environment.
\end{abstract}

Keywords: Student Knowledge About Waste Management, and Environmental Care Behavior.

\begin{abstract}
Abstrak: Tujuan dari penelitian ini adalah untuk memperoleh gambaran tentang hubungan antara pengetahuan mahasiswa tentang pengelolaan sampahdengan perilaku peduli lingkungan. Diharapkan mahasiswa dapat menyadari pentingnya berprilaku peduli lingkungan.Penelitian ini menggunakan metode survei dengan pendekatan korelasional, populasi penelitian mahasiswa STKIP Melawi dan sampel mahasiswa ini adalah 100 yang diambil secara random sampling. Data dikumpulkan menggunakan formulir instrumen berupa butir pernyataan dan pertanyaan. Analisis dan interpretasi data yang menunjukkan, terdapat hubungan positif antara pengetahuan mahasiswa tentang pengelolaan sampah dengan perilaku peduli lingkungan. Kontribusi yang diberikan variabel pengetahuan mahasiswa tentang pengelolaan sampah terhadap perilaku peduli lingkungan sebesar 46,1\%.Temuan penelitian ini menyimpulkan adanya peningkatan pengetahuan mahasiswa tentang pengelolaan sampah dengan perilaku peduli lingkungan dapat meningkatkan mahasiswa akan pentingnya menjaga lingkungan.

Kata Kunci: Pengetahuan Mahasiswa Tentang Pengelolaan Sampah, dan Perilaku Peduli Lingkungan.
\end{abstract}

etiap kegiatan yang dilakukan
manusia selalu menghasilkan bahan yang tidak digunakan lagi yang disebut sampah.Oleh karena itu dimanapun 
manusia hidup selalu menimbulkan sampah.Menurut Didik (2010: 309) sampah mempunyai pengaruhnya terhadap kesehatan, diantaranya adalah sebagai sarang vektor penyakit, sumber infeksi, sumber pencemar air maupuan tanah, disamping masalah estetika. Dampak lain dari pembuangan sampah yang tidak benar, menyebabkan penumpukan sampah diberbagai tempat. Masalah sampah ini merupakan masalah sosial, dan oleh karenanya masalah tersebut juga dipecahkan melalui pendekatan sosial dan sudah selayaknya menjadi kepedulian kita mencari solusi dengan suatu pengetahuan dan perilaku manusia. Berdasarkan KLH (2008:7) hasil survey Kementrian Lingkungan Hidup bekerjasama dengan JICA (Japan International Coorporation Agency),pada umumnya masyarakat tidak melakukan pemilahan sampah terdahulu sebelum sampah dibuang. Pengelolaan sampah dengan upaya-upaya untuk mengurangi sampah (reduce), menggunakan kembali barang yang masih layak pakai (reuse), mendaur ulang sampah (recycle).Penerapan prinsip 3R ini tidaklah mudah, masyarakat masih sulit untuk meninggalkan kebiasaan yang telah turun temurun. Untuk mengubahnya dibutuhkan waktu yang lama dan proses yang panjang karena akan menyangkut nilai, persepsi, pengetahuan, dan sikap yang selama ini melekat pada kehidupan masyarakat. Strategi dalam mengatasi masalah sampah perlu juga merubah perilaku masyarakat agar lebih peduli dan terlibat dalam pemecahan masalah, serta mengambil tindakan untuk memperbaiki lingkungannya. Perilaku menurut Bloom adalah tindakan yang berbentuk nyata dari pengetahuan dan sikap.pendapat Bloom tersebut dibuktikan oleh Arya Gusti dan B. Isyandi (2015) dalam hasil penelitiannya yang menyatakan bahwa pengetahuan memiliki hubungan yang positif dengan perilaku pengelolaan sampah berkelanjutan. Hal senada juga dikemukakan Norshariani (2016) dalam hasil penelitiannya yang menyatakan bahwa terdapat hubungan yang tinggi antara pengetahuan, internal dan faktor lingkungan hidup dengan perilaku perawatan lingkungan.Dalam penelitian ini yang menjadi subjek adalah mahasiswa.Meskipun mahasiswa berada pada tingkatan yang tinggi dalam pelajar, namun masih ada beberapa mahasiswa yang membuang sampah sembarangan dan kurang peduli terhadap lingkungan.Hal ini menjadi landasan kuat penulis untuk melakukan penelitian tentang hubungan pengetahuan pengelolaan dengan perilaku peduli lingkungan di Sekolah Tinggi Keguruan dan Ilmu Pendidikan (STKIP) Melawi.Rumusan permasalah penelitian ini ialah; apakah terdapat hubungan antara pengetahuan mahasiswa tentang 
pengelolaan sampah dengan perilaku peduli lingkungan?Sedangkan tujuan dari penelitian ini adalah untuk memperoleh gambaran tentang hubungan antara pengetahuan mahasiswa tentang pengelolaan sampah dengan perilaku peduli lingkungan.

Peduli lingkungan merupakan sikap dan tindakan yang selalu berupaya mencegah kerusakan lingkungan alam di sekitarnya dan pengembangkan upayaupaya untuk memperbaiki kerusakan alam yang sudah terjadi.Menurut Hamzah (2013:43) peduli lingkungan adalah wujud sikap mental individu yang direfleksikan dalam perilakunya baik lingkungan fisik, biologis dan sosial.Perilaku peduli lingkungan adalah aktivitas seseorang terhadap stimulus yang memunculkan suatu tindakan yang berkaitan dengan upaya untuk mempertahankan dan meningkatkan kepedulian lingkungan baik fisik, biologis dan sosial dalam kehidupan sehari - hari.

Pengetahuan merupakan hasil kegiatan keilmuan atau pikiran yang mengkombinasikan sensasi-sensasi pokok. Lebih lanjut dikatakan, bahwa pengetahuan adalah hasil proses yang rumit dimana objek luar merangsang panca indra atau lebih yang menyebabkan perubahan dalam organ badan. Manusia mencari pengetahuan dengan harapan bahwa pengetahuan tadi dapat berguna baginya untuk membantu memecahkan masalah kehidupan yang dihadapinya (Thomas L Good et.al. 1990:130-131).

Sesuai yang dijelaskan oleh Bloom (1979: 201-204), pengetahuan diartikan sebagai ingatan khusus dan ingatan umum mengenai berbagai metode dan proses atau ingatan kembali tentang pola, struktur atau keadaan. Aspek pengetahuan diklarifikasikan dalam tiga kelompok dan diciri menjadi Sembilan aspek, yaitu (1) pengetahuan mengenai hal-hal yang bersifat khusus meliputi: istilah dan fakta, (2) pengetahuan tentang cara untuk mengenai maalah-masalah khusus meliputi: kebiasaan, kecendrungan, klasifikasi, kategori, metode dan (3) pengetahuan tentang kaidah yang bersifat universal meliputi: prinsip, teori, dan struktur. Pengetahuan akan selalu berkembang seiring dengan berbagai penelitian, perkembangan bukti untuk pembenaran pengetahuan tersebut dan kritik-kritik baru untuk memecahkan masalah. Sasaran penelitian ini adalah pengetahuan mahasiswa tentang pengelolaan sampah.

Berdasarkan Undang-Undang Republik Indonesia Nomor 18 tahun 2008 tentang pengelolaan sampah, sampah merupakan sisa kegiatan sehari-hari manusia atau proses alam yang berbentuk padat. Pengelolaan sampah merupakan kegiatan yang sistematis, menyeluruh, dan 
berkesinambungan yang meliputi pengurangan dan penanganan sampah. Tchobanoglous (1977) berpendapat bahawa pengelolaan sampah adalah suatu bidang kegiatan yang berkaitan dengan pengaturan terhadap timbulnya, penyimpanan, pengumpulan, pemindahan dan pengangkutan, pengolahan dan pembuangan sampah dengan suatu cara yang sesuai dengan prinsip terbaik dari kesehatan masyarakat, ekonomi, teknik, konservasi, estetika, dan berbagai pertimbangan lingkungan lainnya dengan memperhatikan sikap masyarakat.

Miller (2008) menyatakan bahwa sampah dikelola menjadi tiga tahapan utama, tahapan tersebut dapat dilihat pada gambar berikut.



Gambar 1. Tahapan Pengelolaan Sampah

Solusi dalam pengelolaan sampah dapat dilakukan dengan pemilihan sampah yang dilakukan di sumber sampah selanjutnya dikelola dengan menggunakan prinsip 3R,perilaku pengelolaan sampah dengan upaya-upaya untuk mengurangi sampah (reduce), menggunakan kembali barang yang masih layak pakai (reuse), mendaur ulang sampah (recycle) (KLH, 2008).Dengan demikian pengetahuan tentang pengelolaan sampah adalah pengetahuan yang meliputi pengetahuan tentang istiah, fakta dan kebiasaan serta pengetahuan yang bersifat universal meliputi prinsip tentang pengelolaan sampah.

\section{METODE PENELITIAN}

Metode penelitian yang digunakan adalah metode survey dengan rancangan.Informasi yang diperoleh dari responden dikumpulkan berdasarkan fenomena yang terjadi pada saat penelitian ini dilakukan.Penelitian ini menggunakan variabel bebas yaitu, pengetahuan tentang pengelolaan saampah (X), sertavariabel terikat yaitu,perilaku peduli lingkungan 
(Y).

Dalam penelitian ini yang menjadi populasi adalah mahasiswa Sekolah Tinggi Keguruan dan Ilmu Pendidikan (STKIP) Melawi. Populasi tersebut kemudian akan diambil sampelnya. Dari pra survei yang dilakukan pada lokasi penelitian diketahui populasi target berjumlah sebesar 1.117 orang. Pengambilan sampel dilakukan secara acak tanpa memperhatikan strata yang ada dalam populasi (simple random sampling), diperoleh sampel yang diambil dalam penelitian ini berjumlah 100 mahasiswa.

Pengumpulan data pada penelitian ini adalah dengan menggunakan kuesioner, sedangkan alat pengumpul data dengan menggunakan angket. Penelitian ini menggunakan tiga buah instrument untuk mengukur tiga variabel yaitu perilaku peduli lingkungan (Y) sebagai variabel terikat, pengetahuan mahasiswa tentang pengelolaan sampah $(\mathrm{X})$ sebagai variabel bebas. Data yang diperoleh dari hasil penelitian, dianalisis menggunakan program SPSS 17.0 dengan uji statistik korelasi dan regresi linier sederhana serta korelasi dan regresi.

\section{HASIL DAN PEMBAHASAN}

Hasil penghitungan uji normalitas galat taksiran pengetahuan mahasiswa tentang pengelolaan sampah dengan perilaku peduli lingkungan diperoleh $\mathrm{L}_{\text {hitung }}$ sebesar 0,071 sedangkan nilai kritis $\mathrm{L}_{\text {tabel }}$ pada taraf signifikansi 0,05 dan $n=100$ sebesar 0,089. Dengan membandingkan $\mathrm{L}_{\text {hitung }}$ dengan $\mathrm{L}_{\text {tabel }}$ ternyata $\mathrm{L}_{\text {hitung }}<\mathrm{L}_{\text {tabel }}(0,071<0,089)$, $\mathrm{H}_{0}$ yang menyatakan data berdistribusi normal diterima dan dapat disimpulkan data berdistribusi normal, sehingga dapat dilanjutkan uji korelasi linier sederhana.Hasil uji korelasi, koefisien korelasi untuk persamaan garis $\mathrm{X}_{1}$ terhadap $Y$ signifikan hal ini terlihat dari nilai koefisien korelasi sebesar 0,679 dengan nilai Sig. (2-tailed) $0,000<0,05$. Persamaan regresi sederhana: $\hat{\mathrm{Y}}=51,530$ $+1,356 \mathrm{X}_{1}$. Hasil penghitungan terlihat antara pengetahuan mahasiswa tentang pengelolaan sampah dengan perilaku peduli lingkungan terdapat hubungan yang positif dan signifikan.Kontribusi yang diberikan variabel pengetahuan mahasiswa tentang pengelolaan sampah terhadap perilaku peduli lingkungan sebesar $46,1 \%$. Angka ini menunjukkan sumbangan yang sangat berarti, dimana perilaku peduli lingkungan akan berubah sebesar 46,1\% karena adanya sumbangan pengetahuan mahasiswa tentang pengelolaan sampah.

Dari hasil analisis data, menunjukkan bahwa terdapat hubungan yang signifikan antara pengetahuan mahasiswa tentang pengelolaan sampah dengan perilaku peduli lingkungan.Keadaan ini dapat diartikan bahwa semakin tinggi pengetahuan mahasiswa tentang pengelolaan sampah 
selalu diikuti tingginya perilaku peduli lingkungan.Hal ini juga berlaku sebaliknya, semakin tidak sesuai pengetahuan mahasiswa tentang pengelolaan sampah selalu diikuti rendahnya pengetahuan mahasiswa tentang pengelolaan sampah.Kenyataan ini mengisyaratkan bahwa pengetahuan mahasiswa tentang pengelolaan sampah memberikan sumbangan yang sangat berarti terhadap peningkatan Perilaku peduli lingkungan.

Hubungan yang signifikan antara pengetahuan pengelolaan lingkungan dengan perilaku peduli lingkungan juga dibuktikan dalam penelitian Arya Gusti dan B. Isyandi (2015) dalam hasil penelitiannya yang menyatakan bahwa pengetahuan memiliki hubungan yang positif dengan perilaku pengelolaan sampah berkelanjutan. Hal senada juga dikemukakan Norshariani (2016) dalam hasil penelitiannya yang menyatakan bahwa terdapat hubungan yang tinggi antara pengetahuan, internal dan faktor lingkungan hidup dengan perilaku perawatan lingkungan.

\section{SIMPULAN}

Berdasarkan hasil pembahasan studi korelasi antara variabel pengetahuan pengelolaan sampah dengan perilaku peduli lingkungan dapat dirumuskan maka dapat ditarik kesimpulan terdapat hubungan positif antara pengetahuan mahasiswa tentang pengelolaan sampah dengan perilaku peduli lingkungan.Kontribusi yang diberikan variabel pengetahuan mahasiswa tentang pengelolaan sampah terhadap perilaku peduli lingkungan sebesar 46,1\%.Dalam arti semakin tinggi pengetahuan tentang pengelolaan sampah yang dimiliki mahasiswa, maka semakin positif perilaku mereka terhadap peduli lingkungan.

\section{DAFTAR PUSTAKA}

Abd Rahman, N. 2016. "Environmental Care Behaviour Among Aboriginal Students In Malaysia.” International Journal Of Environmental \& Science Education. VOL. 11, NO. 12, 53495366.,1-18.

Bloom, B. S. (ed),.1979. Taxonomy of Educational Objective. London: Longman Ltd.

Good, T. L,. Brophy, J. E. 1990. Educational Psychology. New York: Longman.

Gusti, A. dan Isyandi, B. 2015. "Hubungan Pengetahuan, Sikap dan Intensi Perilaku Pengelolaan Sampah Berkelanjutan Pada Siswa Sekolah Dasar di Kota Padang". Jurnal Dinamika Lingkungan Indonesia. ISSN 2356-2226 Vol 2, No. 2. 1-8.

KLH. 2008. Panduan Praktis Pemilahan Sampah. Jakarta: KLH. Miller. 200). Environment Science. Canada: Thomoson. 
Jurnal Pendidikan Dasar, 7 (2), Desember 2019

Sarudji, D. 2010. Kesehatan Undang-Undang Republik Indonesia Lingkungan. Bandung: Karya Putra Nomor 18 Tahun 2008 tentang Darwati. Pengelolaan Sampah. Kementrian Syukri, H. 2013. Pendidikan Lingkungan: Sekelumit Wawasan lingkungan hidup. Diakses dari: http://www.menlh.go.id/DATA/UU1 Pengantar. Bandung: Refika Aditama. 8-2008.pdf. (diakses pada tanggal 12 Agustus 2018]. 